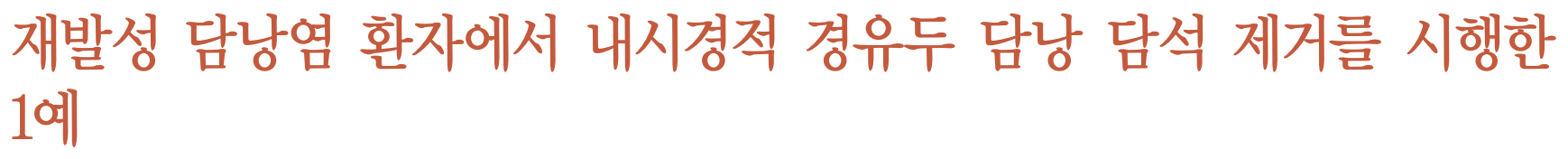

울산대학교 의과대학 울산대학교병원 내과

전희정 · 이병욱

\title{
Endoscopic Transpapillary Gallstone Removal with Recurrent Acute Cholecystitis
}

\author{
Hee Jeong Jeon, Byung Uk Lee \\ Department of Internal Medicine, Ulsan University Hospital, University of Ulsan College of Medicine, Ulsan, Korea
}

We report a case of successfully removed gallstone by endoscopic transpapillary approach with recurrent acute cholecystitis. An 84-year-old man presented with acute calculous cholecystitis. He is concurrently diagnosed with colon cancer at the time of admission. After percutaneous transhepatic gallbladder drainage (PTGBD), He was discharged. After a total of seven PTGBD exchanges for three years, we successfully removed gallstone via an endoscopic transpapillary approach, and no recurrence was reported during the 27-month follow-up period. This procedure may be performed in patients who can access to the gallbladder through the cystic duct.

Korean J Pancreas Biliary Tract 2017;22(4):193-197

Keywords: Cholecystitis, Cholecystostomy, Endoscopic retrograde cholangiopancreatography $\begin{array}{ll}\text { Received } & \text { Mar. 29, } 2017 \\ \text { Revised } & \text { Apr. 19, } 2017 \\ \text { Accepted } & \text { Apr. 21, 2017 }\end{array}$

Corresponding author : Byung Uk Lee

Department of Internal Medicine, Ulsan University Hospital, University of Ulsan College of Medicine, 877 Bangeojinsunhwando-ro, Dong-gu, Ulsan 44033, Korea

Tel. +82-52-250-8634 Fax. +82-52-250-7048

E-mail; bulee@uuh.ulsan.kr
This is an Open Access article distributed under the terms of the Creative Commons Attribution Non-Commercial License (http:// creativecommons.org/licenses/by-nc/3.0/) which permits unrestricted non-commercial use, distribution, and reproduction in any medium, provided the original work is properly cited.

Copyright $\odot 2017$ by The Korean Journal of Pancreas and Biliary Tract

\section{서 론}

복강경하 담낭절제술은 그 동안 급성 결석성 담낭염의 표준 치료로 이용되어 왔다. 그러나 담낭절제술을 할 수 없는 경우 (환자의 상태가 불량하거나, 수술적 치료의 위험이 큰 경우 또 는 환자가 거부하는 경우 등)에는 경피 경간적 담낭 배액술 (percutaneous transhepatic gallbladder drainage, PTGBD)을 시 행하게 되며 이 역시 증상 완화를 위해 유용한 방법이다. 하지
만 PTGBD를 오랫동안 유지하는 경우 환자가 장기간 도관을 유치해야 하는 불편감이 존재하며 도관을 주기적으로 교체해 야 하고 도관 이탈의 문제점이 발생할 수 있다. 본 증례는 급성 담낭염과 대장암이 동시에 진단된 후 고령을 이유로 수술을 거 부한 환자의 재발하는 급성 결석성 담낭염을 내시경 역행성 담 췌관 조영술(endoscopic retrograde cholangiopancreatography, $\mathrm{ERCP})$ 을 통해 십이지장 유두부를 경유하여 담낭 내 담석을 성 공적으로 제거하여 치료한 경험을 문헌고찰과 함께 보고한다. 


\section{증 례}

84 세 남자 환자가 2일 전 발생한 우상복부 통증으로 내원하 였다. 3 년 전 고혈압과 2 개월 전 당뇨병 진단 후 약물 치료 중이 며 그 이외 질환은 없었다. 3 개월 전부터 음주를 하지 않았고, 60 갑년 흡연력을 가지고 있었다. 내원시 활력 징후는 혈압 $120 / 60 \mathrm{mmHg}$, 맥박 분당 84 회, 호흡수 분당 20 회, 체온 $36.4^{\circ} \mathrm{C}$ 로 정상 소견이었고, 계통 문진에서 복통 이외에 구역, 구토, 황 달, 체중 감소, 발열은 호소하지 않았다. 신체 진찰에서 우상복 부에 압통이 있었고, 머피 징후(Murphy's sign)와 반발통은 없 었다. 간이나 비장종대는 없었다. 일반혈액 검사에서 백혈구 $12,600 / \mathrm{mm}^{3}$ (4,000-10,000), 혈색소 $8.8 \mathrm{~g} / \mathrm{dL}$ (13-18), 혈소판 $182,000 / \mathrm{mm}^{3}(130,000-450,000)$, 생화학 검사에서 혈액요소질 소(blood urea nitrogen) $18.3 \mathrm{mg} / \mathrm{dL}$ (7.8-22), 크레아티닌 1.15 $\mathrm{mg} / \mathrm{dL}$ (0.6-1.2), aspartate aminotransferase/alanine aminotransferase/alkaline phosphatase/r-glutamyl transpeptidase (AST/ALT/ALP/r-GTP) 28/18/80/35 IU/L (0-40/0-40/42$128 / 11-50)$, 총 빌리루빈 $0.5 \mathrm{mg} / \mathrm{dL}(0.2-1.2)$, 혈청 아밀라제 33 $\mathrm{IU} / \mathrm{L}$ (54-168), 혈청 리파제 $13 \mathrm{IU} / \mathrm{L}$ (7-60), 총 단백 $5.4 \mathrm{~g} / \mathrm{dL}$ (6.0-8.0), 알부민 $3.0 \mathrm{~g} / \mathrm{dL}$ (3.1-5.2), C-반응 단백질(C-reactive protein) $23.79 \mathrm{mg} / \mathrm{dL}(0-0.3)$ 였다. 단순 복부 촬영에서 특이 소 견은 없었다.

입원시 시행한 복부 전산화단층촬영(computed tomography, CT)에서 쓸개 목(neck of gallbladder)에 담석이 감입(im- paction)되어 있고 이와 동반된 담낭염이 관찰되었다(Fig. 1) 환자는 증상이 악화되어 $\mathrm{PTGBD}$ 를 시행하였고 CT에서 S상결 장에 대장암으로 의심되는 점막비대가 관찰되어 대장 내시경 검사를 시행한 후 조직학적 검사에서 S상결장의 대장암으로 진단되었다. 환자는 수술적 치료를 거부하고 보존적 치료만 하길 원하여 PTGBD를 유지한 채 퇴원하게 되었다. 환자는 3 년간 외래에서 총 7회의 PTGBD 배액관 교체를 시행하면서 경 과 관찰하던 중 다시 복통이 발생하였고, 혈액 검사에서 AST/ ALT/ALP/r-GTP 289/175/289/317 IU/L, 총 빌리루빈 $0.3 \mathrm{mg} /$ $\mathrm{dL}$ 소견으로 담관염이 추정되었다. CT 검사에서 총담관내 담 석이 관찰되어 $\mathrm{ERCP}$ 를 시행하였고, 총 담관 결석을 제거하고 이어서 PTGBD도 제거하였다. 2 개월 후 환자는 다시 복통이 발생하여 내원하였고 CT 검사상 쓸개 목의 담석에 의한 급성 담낭염이 재발되어 PTGBD를 재삽입하였다(Fig. 2). 환자는 $\mathrm{PTGBD}$ 의 제거를 원하여 4 개월 후 내원하였고 $\mathrm{ERCP}$ 를 시행 하였다. 담도 조영술을 시행하였을 때 담낭관이 총담관의 하 부에서 기시하는 저위합류 담낭관(low lying cystic duct)이 관 찰되었다. 이에 유두절개도(papillotome)의 조작을 통해 담낭 관을 지나 담낭 내 유도선을 위치시켰다. 이후 유도선을 따라 삽입할 수 있는 Trapezoid 바스켓(Trapezoid ${ }^{\mathrm{TM}} \mathrm{RX}$; Boston scientific Corp., Natick, MA, USA)을 담낭 내로 진입시켰고 담 낭관을 통한 바스켓의 이동이 원활함을 확인한 후 담낭 내 담 석을 포획하여 파쇄하여 담석을 모두 십이지장 내로 제거하였 다(Fig. 3). 담낭염의 재발을 막고자 담낭내 직경 $7 \mathrm{Fr}, 10 \mathrm{~cm}$ 길
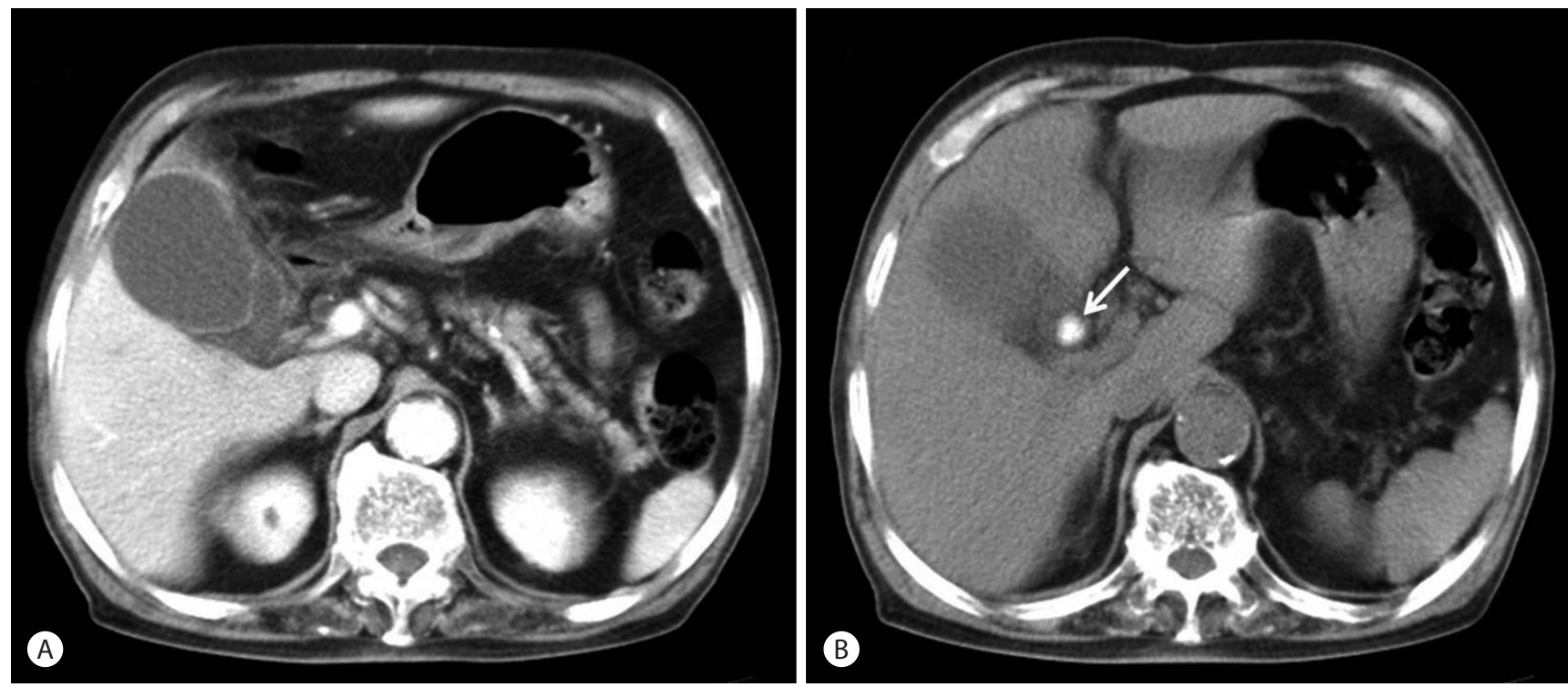

Fig. 1. (A, B) Abdominal computed tomography showed an impacted stone (white arrow) with pericholecystic infiltration. 
이의 이중 돼지꼬리형 플라스틱 배액관(double pigtail plastic stent; Wilson-Cook, Winston-Salem, NC, USA)을 삽입하였고 총담관 내 직경 $10 \mathrm{Fr}, 6 \mathrm{~cm}$ 길이의 일직선형 플라스틱 배액관 (straight plastic stent)을 삽입하였다(Fig. 4). 거치되어 있던 PTGBD를 제거하고 시술을 종료하였으며 특별한 증상 없이 퇴원하였다. 환자는 3 개월 후 입원하여 $\mathrm{ERCP}$ 를 시행하였고 잔여 담석이 없고 특별한 증상을 호소하지 않아 삽입된 플라 스틱 배액관을 모두 제거하고 외래 추적 관찰하였으며 이후 27 개월 동안 담낭염의 재발 없이 임상 경과를 추적 중이다. 한 편 S상결장암은 국소적인 진행과 함께 임파선 전이를 하였고

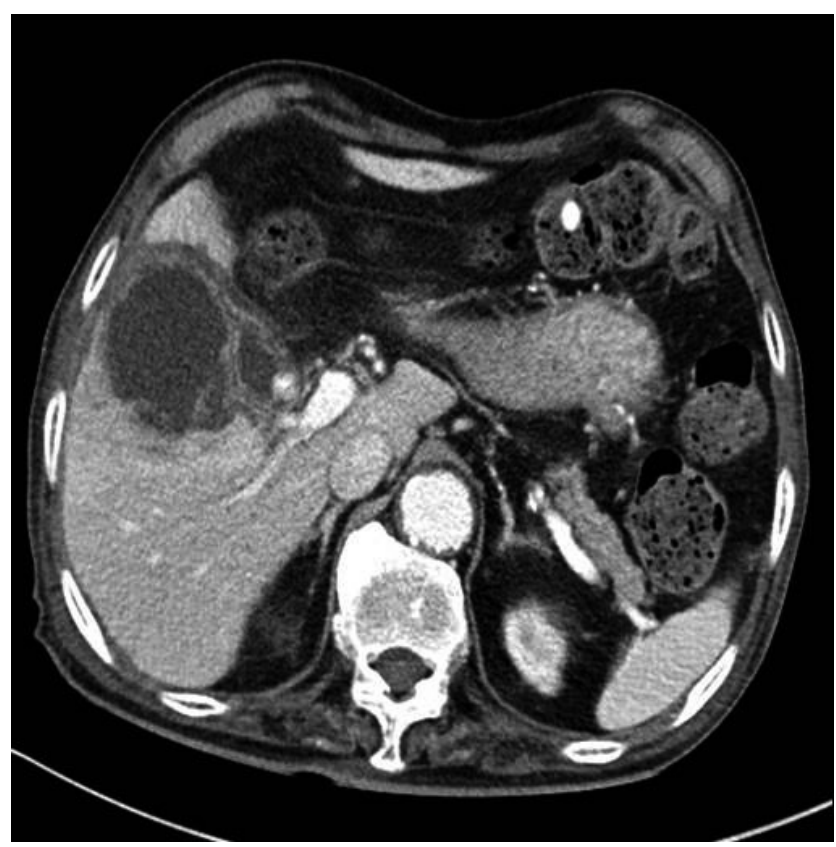

Fig. 2. Abdominal computed tomography showed recurrent cholecystitis after percutaneous transhepatic gallbladder drainage removal.
혈변과 빈혈이 있어 보존적 치료를 하고 있다.

\section{고 찰}

급성 담석성 담낭염의 기본 치료법은 복강경하 담낭 절제술 이며 안전한 수술이다. 하지만 본 증례의 환자는 고령이며 함 께 진단된 대장암으로 인해 수술적 치료를 하지 않고 PTGBD 를 시행 후 외래 추적 관찰하게 되었다. 급성 담석성 담낭염에 서 PTGBD를 삽입 후 급성 담낭염이 호전된 후에 이를 제거할 경우 담낭염이 재발될 확률은 문헌에 따르면 $33-41 \%$ 이며 ${ }^{1}$ 본 환자의 경우에도 제거 2개월 후 담낭염이 재발하였다. 이런 경 우 수술을 권유하거나 PTGBD를 계속 유지할 수 있겠으며 경 피 경간적 담낭경 검사-percutaneous transhepatic cholecystos$\operatorname{copy})^{2,3}$ 를 시행하여 담석을 제거할 수 있으며 비교적 안전하고 유용하게 시행될 수 있다. 또 초음파 유도하 담낭 배액술 ${ }^{4}$ 이나 경유두 담낭 배액술도 시행할 수 있다. 경유두 담낭 배액술은 $\mathrm{ERCP}$ 를 시행하면서 십이지장 유두부를 통해 담낭관을 경유 하여 담낭을 배액하는 방법으로 1984년 Kozarek이 최초로 보 고하였다. 국내에서는 복강경 담낭절제술 후 잔여 담낭관에 감 돈된 담낭 관석으로 인해 발생한 미리찌 증후군 환자에서 담낭 관에 플라스틱 스텐트를 삽입하고 충분한 기간 ursodeoxycholic acid (Ursa ${ }^{\circledR}$; Daewoong, Seoul, Korea)를 투여한 후 ERCP를 시행하여 담낭 관석을 성공적으로 제거한 증례 ${ }^{6}$ 와 잔여 담낭관 에 감돈된 담낭관석을 Trapezoid 바스켓(Trapezoid ${ }^{\mathrm{TM}} \mathrm{RX}$; Boston scientific Corp.)을 이용하여 제거한 증례도 보고하였 다. ${ }^{7}$ 그러나 이 시술은 일반적으로 시행되기 어려운데 담낭관 내로의 선택적 삽관이 일반적으로는 어렵기 때문이다. 문헌에 따르면 숙련된 $\mathrm{ERCP}$ 경험자도 $21 \%$ 정도에서 담낭관으로 선
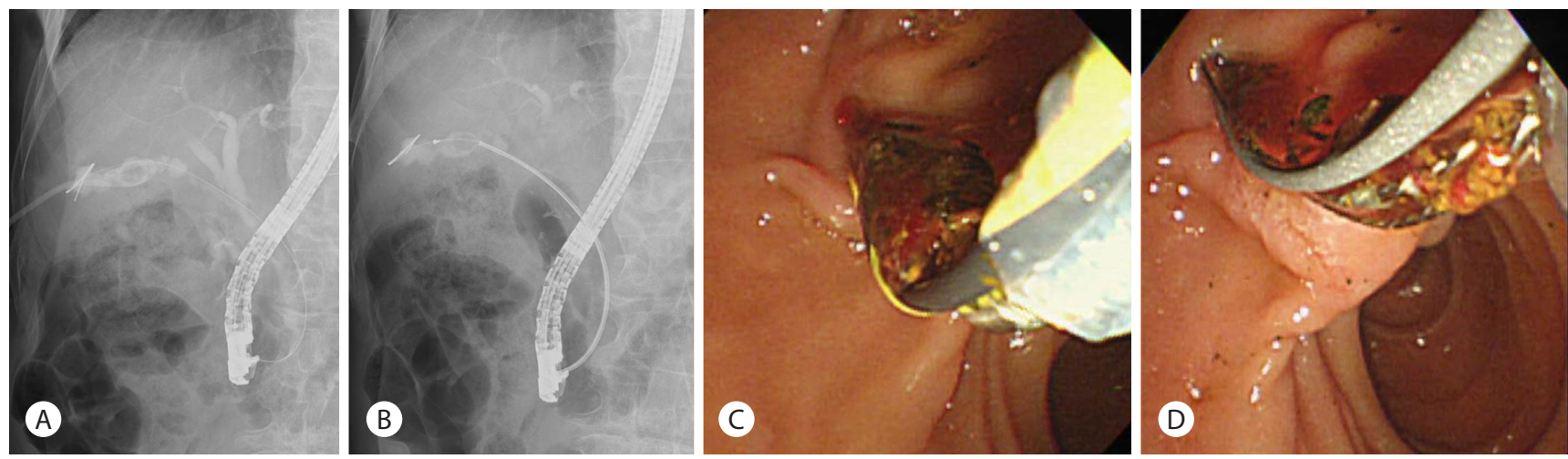

Fig. 3. (A, B) A Trapezoid ${ }^{T M}$ RX basket (Trapezoid ${ }^{T M}$ RX; Boston scientific Corp., Natick, MA, USA) was inserted into the gallbladder and capture the filling defect. (C, D) The gallbladder stone was successfully removed with Trapezoid ${ }^{T \mathrm{M}} \mathrm{RX}$ basket (Trapezoid ${ }^{\mathrm{TM}} \mathrm{RX}$; Boston scientific Corp.). 


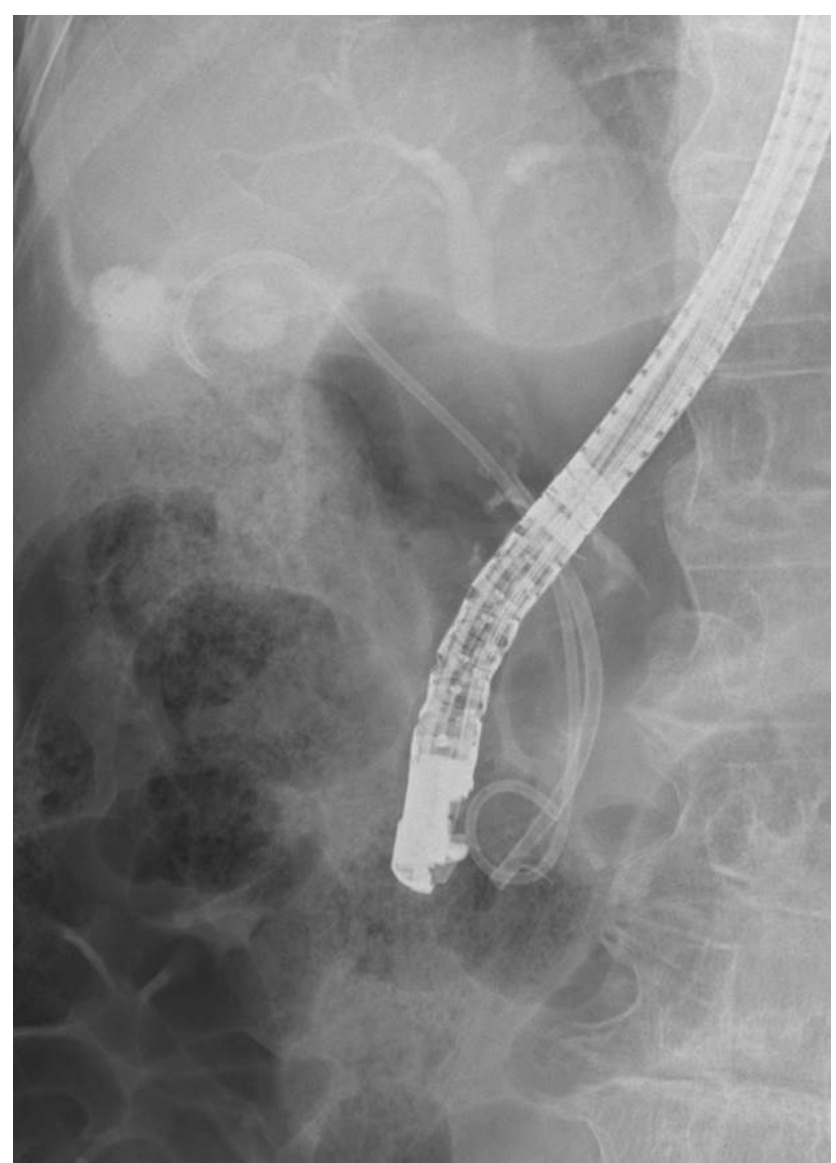

Fig. 4. Two plastic stents were placed in the gallbladder (double pigtail stent) and common bile duct (straight plastic stent), respectively.

택적 삽관에 실패한다고 보고하고 있다. ${ }^{8}$ 본 환자의 경우 담낭 관이 비교적 넓었고 유도선의 진입이 가능하였으며 이어서 유 도선을 따라 삽입할 수 있는 Trapezoid 바스켓(Trapezoid ${ }^{\mathrm{TM}}$ RX; Boston scientific Corp.)을 담낭 내로 진입시켜 담석을 포 획한 후 파쇄하여 성공적으로 제거할 수 있었다. 일단 담낭관 으로 선택적 삽관이 성공하더라도 추가적인 시술 중 담낭관 파 열이나 바스켓 감돈 등이 발생할 수 있으므로 주의를 요한다. 본 증례의 경우 담낭관이 간외 담도의 아랫쪽에서 기시하는 저 위합류 담낭관(low lying cystic duct)으로 쉽게 담낭관으로 선 택적 삽관이 가능하였고 담낭관의 직경이 넓어 시술에 용이하 였다. 유도선이 삽입된 이후에는 유도선을 따라 삽입할 수 있 는 Trapezoid 바스켓(Trapezoid ${ }^{\mathrm{TM}} \mathrm{RX}$; Boston scientific Corp.) 을 삽입하여 담석의 파쇄를 시도해 볼 수 있으며 한 두 번의 시 술을 통해 충분히 담석을 제거할 수 있을 것으로 보이나 이런 경우 바스켓의 감돈이 발생할 수 있음을 염두에 두어야 한 다. ${ }^{9,10}$
결론적으로 $\mathrm{PTGBD}$ 를 지속적으로 유지해야 하는 상황이 예상되는 환자에서 담도 조영술을 통해 담낭관의 상태를 평가 한 후 $\mathrm{ERCP}$ 를 통해 담낭 내 담석을 제거하는 것은 일부 선택 된 환자에서 충분히 시도할 수 있는 방법이라고 생각된다.

\section{요 약}

급성 결석성 담낭염의 근본적인 치료는 복강경하 담낭절제 술이나 수술이 위험하거나 그 외 여러 가지 이유로 담낭 절제 술을 할 수 없는 경우 경피 경간적 담낭 배액술을 시행할 수 있 다. PTGBD는 급성 증상의 완화를 위한 유용한 방법이나 오랫 동안 PTGBD를 유치할 경우 여러 문제들이 발생할 수 있다.

본 증례는 급성 결석성 담낭염으로 진단된 환자가 PTGBD 를 시행한 후 입원 당시 대장암을 동시에 진단받고 나서 수술 적 치료를 거부하여 $\mathrm{PTGBD}$ 를 제거하였으나 급성 담낭염의 재발로 PTGBD를 3년간 7차례 교체하면서 유지하게 되었고, 이후 내시경 역행성 담췌관 조영술을 시행하여 십이지장 유두 부를 통해 담낭 내 담석을 성공적으로 제거하고, 27 개월간 추 적 관찰하였으나 급성 담낭염의 재발 없이 성공적으로 치료된 증례를 보고하고자 한다.

국문 색인: 결석성 담낭염, 담낭배액술, 내시경 역행성 담췌 관 조영술

\section{Conflicts of Interest}

The author has no conflicts to disclose.

\section{REFERENCES}

1. McKay A, Abulfaraj M, Lipschitz J. Short- and long-term outcomes following percutaneous cholecystostomy for acute cholecystitis in high risk patients. Surg Endosc 2012;26:1343-1351.

2. Kim JH, Park CW, Moon JH, et al. Nonsurgical treatment of gallbladder stones with percutaneous transhepatic cholecystoscopy. Korean J Gastrointest Endosc 1992;12:279-284.

3. Kim HJ, Kim MH, Lee SK, Yoo KS, Seo DW, Min YI. Safety and usefulness of percutaneous transhepatic cholecystoscopic examination (PTCCS) in high-risk surgical patients manifesting acute cholecystitis. Korean J Pancreas Biliary Tract 2000;5:13-19.

4. Jang JW, Lee SS, Song TJ, et al. Endoscopic ultrasound-guided transmural and percutaneous transhepatic gallbladder drainage are comparable for acute cholecystitis. Gastroenterology 2012;142:805-811. 
5. Kozarek RA. Selective cannulation of the cystic duct at time of ERCP. J Clin Gastroenterol 1984;6:37-40.

6. Song CW, Son BK, Choi JH, et al. Endoscopic treatment of Mirizzi syndrome in a patient with low lying cystic duct and remnant cystic duct stone. Korean J Pancreas Biliary Tract 2017;22:46-50.

7. Lee JM, Park JS, Jeong S, et al. Endoscopic treatment of a case of postcholecystectomy Mirizzi syndrome. Korean J Pancreas Biliary Tract 2014;19:199-203.

8. Lee TH, Park DH, Lee SS, et al. Outcomes of endoscopic transpapillary gallbladder stenting for symptomatic gallbladder diseases: a multicenter prospective follow-up study. Endoscopy 2011;43:702-708.

9. Inoue T, Ito K, Ishii N, Kobayashiz Y, Yoneda M. A forward-pulling technique for complicated Trapezoid basket impaction during retrieval of common bile duct stones. Endoscopy 2016;48(S 01):E334-E335.

10. Purohit T, Garg M, Kulkarni A, Thakkar S. Argon plasma coagulation for extraction of an impacted Trapezoid basket in the pancreatic duct. ACG Case Rep J 2015;2:139-141. 